\title{
PENERAPAN MODEL PROBLEM BASED LEARNING BERBANTU MEDIA QUIZIZ UNTUK MENINGKATKAN KEAKTIFAN SISWA DALAM PEMBELAJARAN DARING KELAS XI IPS 1 SMA ISLAM AL AZHAR 7 SOLO BARU TAHUN AJARAN 2020/2020
}

Oleh:

Fitria $^{1}$

\begin{abstract}
Abstrak
Penelitian ini bertujuan untuk meningkatkan keaktifan siswa dalam mengikuti pembelajaran jarak jauh mata pelajaran sosiologi materi diferensiasi dan stratifikasi sosial melalui media game edukasi quiziz. Penelitian ini merupakan penelitian tindakan kelas. Model penelitian tindakan kelas yang digunakan dalam penelitian ini adalah model dari Kurt Lewin. Terdapat empat langkah penelitian tindakan kelas menurut Kurt Lewin, yaitu: perencanaan (planning), tindakan (acting), observasi (observing), dan refleksi (reflecting). Teknik pengumpulan data dalam penelitian ini menggunakan tes, observasi, dan dokumentasi. Berdasarkan hasil penelitian, tingkat keaktifan siswa pada siklus 1 yaitu $70 \%$ dan siklus 2 yaitu $90 \%$. Dengan demikian dapat disimpulkan bahwa media game edukasi quiziz dapat meningkatkan keaktifan siswa dalam mengikuti pembelajaran jarak jauh sosiologi kelas XI IPS 1 materi diferensiasi dan stratifikasi sosial)
\end{abstract}

Kata Kunci: Keaktifan; Penelitian Tindakan Kelas; quiziz

\footnotetext{
${ }^{1}$ Guru Sosiologi SMA Islam Al Azhar 7 Solo Baru, email: fitriabaksoepic@gmail.com
} 


\section{PENDAHULUAN}

Belajar merupakan proses pendidikan di sekolah yang bertujuan untuk menghasilkan perubahan tingkah laku. Perubahan meliputi kognitif, afektif dan psikomotor. Diperlukan keaktifan, partisipasi, dan komunikasi yang efektif antara guru dan siswa. Keberhasilan dalam proses pembelajaran dapat dilihat dari pemahaman konsep, penguasaan materi dan prestasi belajar. Menurut Mulyasa (2002:32), keaktifan siswa dalam pembelajaran sangatlah penting, pembelajaran dikatakan berhasil dan berkualitas apabila seluruhnya atau setidaktidaknya sebagian besar peserta didik terlibat secara aktif, baik fisik, mental maupun sosial dalam proses pembelajaran.

Pendidikan pada era revolusi industri 4.0 memiliki tantangan yang besar. Guru harus mampu berinovasi untuk meningkatkan motivasi dan keaktifan siswa dalam belajar. Peningkatan mutu salah satunya dapat dilakukan melalui pembaharuan media pembelajaran. Sekolah sebagai pengahasil sumber daya manusia harus mampu meningkatkan kulaitas agar lulusanya memiliki kemampuan berdaya saing tinggi.

Pandemi covid 19 yang masuk di Indonesia sejak maret 2020 mendorong pemerintah untuk menerapkan pembelajaran daring yang dikenal dengan istilah pembelajaran jarak jauh. Terjadi perubahan besar di bidang pendidikan dari pembelajaran tatap muka menjadi pembelajaran jarak jauh. Berdasarkan hasil observasi, siswa SMA Islam Al Azhar 7 memerlukan adaptasi yang tinggi dalam melaksanakan pembelajaran jarak jauh. Diperlukan kerjasama yang baik di era pembelajaran jarak jauh antara sekolah, siswa, dan orang tua demi keberhasilan pembelajaran jarak jauh di SMA Islam Al Azhar 7 Solo Baru. Dalam pelaksanaan pembelajaran jarak jauh, tingkat keaktifan peserta didik menurun drastis dibandingkan pada saat pembelajaran tatap muka. Hal ini dibuktikan dengan penurunan prosentase keaktifan dan kehadiran pembelajaran jarak jauh, dibandingkan dengan pembelajaran tatap muka di sekolah.

Tabel 1. Perbandingan Keaktifan Peserta Didik Kelas XI IPS 1 (Sumber: Data Kurikulum SMA Islam Al Azhar 7 Solo Baru)

\begin{tabular}{|c|c|c|}
\hline Keterangan & $\begin{array}{l}\text { Term 1 } \\
\text { Tahun } \\
\text { Pelajaran } \\
\text { 2019/2020 } \\
\text { Pembelaja } \\
\text { ran Tatap } \\
\text { Muka }\end{array}$ & $\begin{array}{l}\text { Term 1 } \\
\text { Tahun } \\
\text { Pelajaran } \\
\text { 2020/2021 } \\
\text { Pembelajar } \\
\text { an Jarak } \\
\text { Jauh }\end{array}$ \\
\hline $\begin{array}{c}\text { Prosentase } \\
\text { kehadiran } \\
\text { dan keaktifan } \\
\text { mengerjakan } \\
\text { tugas }\end{array}$ & $90 \%$ & $50 \%$ \\
\hline
\end{tabular}

Menurut Gagne dan Briggs (dalam Martinis, 2007) faktor-faktor keaktifan belajar adalah memberikan dorongan atau menarik perhatian siswa, menjelaskan 
tujuan intruksional (kemampuan dasar kepada siswa), mengingatkan kompetensi belajar kepada siswa, memberikan stimulus (masalah,topik dan konsep yang akan dipelajari), memberi petunjuk kepada siswa cara mempelajarinya, memunculkan aktivitas, partisipasi siswa dalam kegiatan pembelajaran, memberi umpan balik (feed back), melakukan tes singkat diakhir pembelajaran,dan menyimpulkan setiap materiyang disampaikan di akhir pelajaran.

Kegiatan guru yang dapat meningkatkan keaktifan siswa menurut Moh. Uzer Usman (2009: 26-27) yaitu memberikan motivasi, menjelaskan tujuan instruksional, mengingatkan kompetensi belajar, memberikan stimulus (masalah, topik, konsep), memberikan petunjuk cara mempelajari, memberikan umpan balik, dan menyimpulkan di akhir pembelajaran. Keaktifan dapat ditingkatkan dan diperbaiki dalam keterlibatan siswa pada saat belajar.

Menghadapi beberapa masalah atau tantangan dalam pembelajaran jarak jauuh, guru dituntut untuk dapat menciptakan pembelajaran yang menyenangkan, menarik dan aktif. Walaupun pembelajaran dilaksanakan jarak jauh atau daring, guru harus mampu meningkatkan keaktifan siswa. Keaktifan siswa dapat tercipta melalui penerapan media pembelajaran yang menarik. Salah satu media pembelajaran yang menarik dalam pembelajaran daring adalah memanfaatkan game edukasi quiziz.

Game edukasi quiziz adalah aplikasi pendidikan berbasis game,yang membawa aktivitas multi permaianan dan membuat latihan interaktif yang menyenangkan (Purba, 2019). Penerapan game edukasi quiziz dapat dilakukan siswa dirumah dengan menggunakan perangkat elektronik yang dimiliki seperti smartphone dan laptop. Tidak seperti aplikasi pendidikan lainya game edukasi quiziz memiliki karakter tema, meme, avatar dan musik yang dapat menghibur siswa pada saat proses pembelajaran, latihan atau mengerjakan kuis secara mandiri. Game edukasi quiziz juga memungkinkan antar siswa saling bersaing sehingga mendorong siswa lebih aktif dalam proses pembelajaran dan termotivasi untuk mengerjakan latihan dan kuis dengan harapan mampu memperoleh hasil kuiz yang tinggi. Menurut Dewi (2018) bahwa pembelajaran berbasis permaianan mempunyai potensi yang baik untuk dijadikan sebagai media pembelajaran yang efektif karena dapat merangsang komponen visual dan verbal. 
Pemanfaatan paltform game edukasi quiziz sangat membantu dalam pelaksanaan pembelajaran jarak jauh. Peenggunaan teknologi mempunyai sumbangan besar dalam lembaga pendidikan, termasuk di dalamnya adalah pencapaian tujuan pembelajaran jarak jauh (Korucu \& Alkan, 2011). Tujuan dari penelitian ini adalah untuk meningkatkan keaktifan siswa dalam pembelajaran jarak jauh sosiologi materi stratifikasi dan diferensiasi sosial kelas XI IPS 1 SMA Islam Al Azhar 7 Solo Baru tahun ajaran 2020/2021

\section{METODE PENELITIAN}

Penelitian ini dilaksanakan mulai 13 Oktober 2020 sampai dengan 20 November 2020, meliputi siklus 1 dan siklus 2. Penulis mengambil lokasi penelitian di SMA Islam Al Azhar 7 Solo Baru yang berada di Jl. Solo Baru-Baki, Kudu, Baki, Sukoharjo, Jawa Tengah. Subyek penelitian adalah siswa kelas XI IPS 1 SMA Islam Al Azhar 7 Solo Baru tahun ajaran 2020/2021 yang melibatkan 20 siswa. Alasan pemilihan kelas XI IPS 1 karena terjadi penurunan keaktifan murid saat pembelajaran daring, padahal kelas XI IPS 1 merupakan kelas IPS unggulan. Penurunan keaktifan terlihat saat diskusi dan pembelajaran jarak jauh berlangsung.

Teknik pengumpulan data dalam penelitian ini adalah menggunakan tes dan dokumentasi. Instrumen yang digunakan dalam penelitian ini berupa instrumen tes dan non tes. Adapun instrumen yang digunakan antara lain: 1) instrumen evaluasi kognitif, 2) lembar kerja peserta didik (LKPD). Tes kognitif menggunkan game aplikasi quizziz. Semua tahapan dilaksanakan dengan moda daring menggunakan googleclassroom, whatsappgroup, googlemeet dan quiiziz 3) Penutup, dengan mengisi refleksi. Penelitian ini merupakan penelitian tindakan kelas yang dilaksanakan dalam dua siklus, dengan tahapan setiap siklus adalah perencanaan, tindakan, pengamatan, dan refleksi.

Indikator keberhasilan penelitian ini adalah apabila keaktifan siswa dalam mengikuti pembelajaran jarak jauh sudah diatas $81 \%$ - 100\%. Dalam menganalisis data penulis menggunakan metode kuantitatif deskriptif yaitu menggunakan teknik pemaparan data yang berasal dari statistik kemudian dilakukan pengamatan gambaan secara sistematis akurat mengenai fakta-fakta serta hubungan antar fenomena yang diteliti3. HASIL

Penelitian yang dilakukan oleh peneliti diperoleh hasil dari tiap-tiap tindakan kelas. Hasil penelitian bisa 
dijabarkan sebagai berikut:

\section{Pra tindakan}

Sebelum melakukan penelitian tindakan kelas, peneliti terlebih dahulu mengadakan observasi awal kegiatan pembelajaran dilakukan pada awal bulan Oktober 2020. Peneliti melakukan pengamatan pelaksanaan pembelajaran jarak jauh di SMA Islam Al Azhar 7 Solo Baru. Pembelajaran jarak jauh menggunakan cisco webex dan google meet untuk sinkronus, dan untuk pembelajaran asinkronus menggunakan googleclasroom, quiziz, dan googleform yang dipilih sesuai kebutuhan guru dalam melaksanakan pembelajaran jarak jauh . Pelaksanaan pembelajaran jarak jauh sejak bulan maret, membuat tingkat keaktifan peserta didik menjadi menurun, kurang aktif dalam diskusi, terlambat mengumpulkan tugas, dan terlihat cenderung pasif dalam pembelajaran sinkronus. Tingkat keaktifan rendah ini berakibat pada menurunya hasil belajar siswa. Terlihat dari mulai prosentase kehadiran, kerajinan mengumpulkan tugas serta NA pada saat PH dan PTS 1.

Dari observasi yang telah dilakukan maka dapat disimpulkan bahwa dalam pelaksanaan pembelajaran jarak jauh, tingkat keaktifan peserta didik menurun drastis dibandingkan saat tatap muka. Hal ini dibuktikan dengan penurunan prosentase keaktifan dan kehadiran saat pandemi, dibandingkan dengan saat tatap muka di sekolah.

\section{Tabel 2. perbandingan keaktifan Peserta Didik kelas XI IPS 1}

(Sumber: Data Kurikulum SMA Islam Al Azhar 7 Solo Baru)

\begin{tabular}{|c|l|l|}
\hline Keterangan & $\begin{array}{l}\text { Term } 1 \\
\text { Tahun } \\
\text { Pelajaran } \\
\text { 2019/2020 } \\
\text { Tatap muka }\end{array}$ & $\begin{array}{l}\text { Term } \\
\text { Tahun } \\
\text { Pelajaran } \\
\text { 2020/2021 } \\
\text { pembelajaran } \\
\text { jarak jauh }\end{array}$ \\
\hline $\begin{array}{c}\text { Prosentase } \\
\text { kehadiran } \\
\text { dan keaktifan } \\
\text { mengerjakan } \\
\text { tugas }\end{array}$ & $90 \%$ & $50 \%$ \\
\hline
\end{tabular}

Berangkat dari permasalahan tersebut, maka perlu dilakukan perbaikan dan peningkatan keaktifan pembelajaran jarak jauh. Oleh karena itu, peneliti mengadakan penelitian tindakan kelas yang bertujuan untuk meningkatkan keaktifan peserta didik dengan menggunakan model pembelajaran Problem Based Learning dengan berbantuan game edukasi quizziz untuk alat evaluasi pengetahuan. Metode tersebut merupakan metode mengarakan peserta didik untuk mengidentifikasi permasalaan yang ada dalam masyarakat kemudian perserta didik memberikan alternatif solusi dari permaslahan tersebut dengan langkah-langka yang sesuai 
dengan sintak pembelajaran problem based learning. Selanjutnya peneliti menyiapkan instrumen yang akan digunakan dalam penelitian antara lain rencana pelaksanaan pembelajaran, bahan ajar, media pembelajaran, dan instrumen penilaian.

\section{Pelaksanaan Siklus 1}

$$
\text { Pelaksanaan siklus I }
$$

dilaksanakan dalam satu kalitindakan. Pelaksanaan dilakukan pada Rabu 22 Oktober 2020. Adapun kegiatan perencanaan terdiri dari: Menganalisis KI, KD, IPK, Tujuan Pembelajaran dan Materi, Membuat RPP dengan metode problem solving dengan berbantuan evaluasi pembelajaran menggunakan game edukatif quizziz. Membuat bahan ajar, LKPD, Media Pembelajaran, evaluasi yang inovatif, kreatif dan interaktif, terintegrasi TPACK Mengintegrasilan bahan ajar, LKPD, Media Pembelajaran, video pembelajaran, dan game edukatif quizziz dengan google classroom.

Pelaksanaan Sesuai dengan RPP, kegiatan pembelajaran dilaksanakan dengan metode pembelajaran Problem based learning sinkronus dengan google meet dan asinkronus dengan google classroom dan quiziz. Bahan ajar, artikel, dan materi ppt dibagikan $\mathrm{H}-1$ melalui WA grup. Pada saat sinkronus di google meet peneliti menyampaikan tujuan pembelajaran, alur pembelajaran problem solving, menyampaikan materi, dan penugasan melalui LKPD.

Peneliti menampilkan gambar untuk menarik perhatian siswa. Kemudian mendiskusikan artikel yang ada di media online. Peserta didik menanggapi dan mencoba menawarkan solusi. Peserta didik lain menanggapi. Di akhir diskusi, guru menyimpulkan bersama peserta didik. Peneliti menjelaskan materi mengenai pengertian dan dasar stratifikasi sosial melalui googlemeet. Terjadi tanya jawab dengan peserta didik untuk merangsang keaktifan mereka.Setelah penjelasan materi selesai peneliti memberikan kesempatan kepada siswa untuk bertanya.

Dalam tindakan pertama ini permasalahan ditentukan oleh peneliti. Masalah yang disajikan untuk peserta didik diambil dari link media online berkaitan, dengan artis pamer saldo ATM di sosmed. Pelaksanaan problem solving pada tindakan pertama ini dilaksanakan secara individual.

Penilaian pada tindakan pertama mengerjakan soal di game edukasi 
quizziz. Keaktifan siswa dalam quiziz terlihat dalam tabel berikut:

Tabel 3. Katagori Tingkat Keatifan Belajar Siswa Mengerjakan quiziz

\begin{tabular}{|l|l|l|}
\hline No & Rentang Skor & Katagori \\
\hline 1 & $91 \%-100 \%$ & $\begin{array}{l}\text { Sangat } \\
\text { Tinggi }\end{array}$ \\
\hline 2 & $81 \%-90 \%$ & Tinggi \\
\hline 3 & $71 \%-80 \%$ & Cukup \\
\hline 4 & $36 \%-70 \%$ & Rendah \\
\hline 5 & $20 \%-35 \%$ & $\begin{array}{l}\text { Sangat } \\
\text { Rendah }\end{array}$ \\
\hline
\end{tabular}

Pengamatan dilakukan untuk melihat perilaku siswa dalam pembelajaran. Hasil dari pengamatan pada siklus I tindakan pertama adalah: Peserta didik antusias dalam mengikuti pembelajaran jarak jauh, dibuktikan dengan aktif berdiskusi di google meet, Penyelesaian masalah belum bisa menggabungkan dengan teori/materi yang dipelajari, Sebagian peserta didik belum mengerjakan soal di quiziz.

Pelaksanaan pembelajaran pada siklus 1 ini sudah sesuai dengan rencana. Refleksi-refleksinya antara lain :Mengoptimalkan sinkronus di google meet , peserta didik yang lebih aktif berdiskusi daripada guru, Mendorong keaktifan peserta didik yang masih belum berani berpendapat, Mendorong dan mengingatkan peserta didik setelah join di google meet, untuk mengerjakan soal by quiziz

Pelaksanaan siklus 2 dilakukan dalam satu kali tindakan. Pelaksanaan pada Senin, 2 Nov 2020. Adapun kegiatan perencanaan terdiri dari: 1)Menganalisis KI, KD, IPK, Tujuan Pembelajaran dan Materi, 2) Membuat RPP dengan metode problem solving dengan berbantuan evaluasi pembelajaran menggunakan game edukatif quizziz, 3) Membuat bahan ajar, LKPD, Media Pembelajaran, evaluasi yang inovatif, kreatif dan interaktif, terintegrasi TPACK, 4) Mengintegrasilan bahan ajar, LKPD, Media Pembelajaran, video pembelajaran, dan game edukatif quizziz dengan google classroom, 5) Membagikan poster sederhana menggunakan canva, untuk agenda belajar hari ini.

Dalam siklus 2, Sesuai dengan RPP, kegiatan pembelajaran dilaksanakan dengan metode pembelajaran Problem solving sinkronus dengan google meet dan asinkronus dengan googleclassroom dan quiziz. Bahan ajar, artikel, poster agenda kegiatan dan materi ppt dibagikan H-1 melalui WA grup. Pada saat sinkronus di 
googlemeet peneliti menyampaikan tujuan pembelajaran, alur pembelajaran problem solving, menyampaikan materi, dan penugasan melalui LKPD.

Peneliti melakukan presensi di google clasroom. Saat sinkronus langsung digunakan untuk diskusi artikel tentang siapa penerus raja keraton Jogja yang diambil dari media online. Kemudian mendiskusikan nya bersama. Peserta didik menanggapi dan mencoba menawarkan solusi. Peserta didik lain menanggapi. Di akhir diskusi, guru menyimpulkan bersama peserta didik. Peneliti menjelaskan materi mengenai sifat dan stratifikasi sosial di Indonesia melalui googlemeet. Terjadi tanya jawab dengan peserta didik untuk merangsang keaktifan mereka. Setelah penjelasan materi selesai peneliti memberikan kesempatan pada siswa untuk bertanya.

Dalam tindakan pertama ini permasalahan ditentukan oleh peneliti. Masalah yang disajikan untuk peserta didik diambil dari link media online berkaitan dengan penerus keraton jogja. Pelaksanaan problem solving pada tindakan kedua ini dilaksanakan secara individual

Penilaian pada tindakan pertama mengerjakan soal di game edukasi quizziz. Keaktifan siswa dalam quiziz terlihat dalam tabel beriku Dari data di atas, tingkatan keaktifan nya adalah sbb:
Tabel 4. Katagori Tingkat Keatifan Belajar Siswa Mengerjakan quiziz Siklus 2

\begin{tabular}{|l|c|l|}
\hline No & Rentang Skor & Katagori \\
\hline 1 & $91 \%-100 \%$ & $\begin{array}{l}\text { Sangat } \\
\text { Tinggi }\end{array}$ \\
\hline 2 & $81 \%-90 \%$ & Tinggi \\
\hline 3 & $71 \%-80 \%$ & Cukup \\
\hline 4 & $36 \%-70 \%$ & Rendah \\
\hline 5 & $20 \%-35 \%$ & $\begin{array}{l}\text { Sangat } \\
\text { Rendah }\end{array}$ \\
\hline
\end{tabular}

Pengamatan dilakukan untuk melihat perilaku siswa dalam pembelajaran. Hasil dari pengamatan pada siklus 2 adalah: Peserta didik antusias dalam mengikuti pembelajaran jarak jauh, yang dibuktikan dengan aktif berdiskusi di google meet. Penyelesaian masalah sudah memasukan materi/teori . Sebanyak $95 \%$ peserta didik mengerjakan soal di quiziz.

Pelaksanaan pembelajaran pada siklus 2 ini sudah sesuai dengan rencana. Refleksi-refleksinya antara lain: Mengoptimalkan sinkronus di google meet dimana peserta didik yang lebih aktif berdiskusi daripada guru, Peserta didik sudah aktif dalam berdiskusi dan mengerjakan soal di game edukasi quiziz. 


\section{DISKUSI}

Pandemi covid-19 yang masuk ke Indonesia sejak maret 2020, mengharuskan pembelajaran tatap muka diganti dengan pembelajaran jarak jauh (pembelajaran jarak jauh). Pendidikan jarak jauh dilakukan dengan menggunakan berbagai platform. Guru perlu merancang pembelajaran yang menarik dan bermakna. Salah satu rancangan pembelajaran yang menarik dan bermakna adalah metode pembelajaran problem based solving dengan berbantuan game edukasi quizziz. Hasil penelitian, Menunjukan bahwa etode ini terbukti mampu menarik minat siswa untuk mengikuti pembelajaran jaraj jauh (pembelajaran jarak jauh) dan meningkatkan prestasi belajar.

Siswa dilatih untuk belajar mandiri mengidentifikasi bentuk diferensiasi, dan dasar stratifikasi. Hal ini tebukti siswa mampu merumuskan dan mengkomunikasikan materi diferensiasi dan straifikasi sosialyang mereka temui dalam kehidupan sehari-hari.

Dalam penelitian ini menggunakan evaluasi quiziz.Tidak seperti aplikasi pendidikan lainya game edukasi quiziz memiliki karakter tema, meme, avatar dan musik yang dapat menghibur siswa pada saat proses pembelajaran, latihan atau mengerjakan kuis secara mandiri. Game edukasi quiziz juga memungkinkan antar siswa saling bersaing sehingga mendorong siswa lebih aktif dalam proses pembelajaran .

Penerapan game edukasi quiziz mampu meningkatkan keaktifan peserta didik, terlihat dari grafik berikut:

\section{GRAFIK KEAKTIFAN MURID}

KELAS XI IPS 1

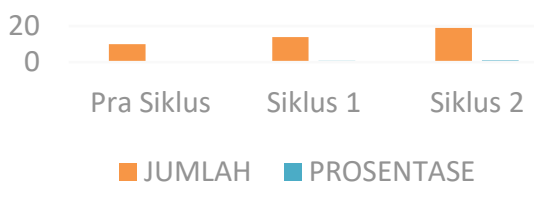

Pada siklus 1 ini terdapat 6 peserta didik yang tidak mengumpulkan tugas sesuai yang diperintahkan, sehingga hanya 14 anak yang aktif mengerjakan tugas dengan baik. Dengan demikian, prosentase keaktifan peserta didik dalam mengerjakan tugas di kelas XI IPS 1 adalah $70 \%$.

Pada siklus 2 ini terdapat 1 peserta didik yang tidak mengerjakan sesuai yang diperintahkan, sehingga ada 19 anak yang aktif mengerjakan tugas dengan baik. Dengan demikian, prosentase keaktifan peserta didik dalam mengerjakan soal di game edukasi quiziz kelas XI IPS 1 adalah $95 \%$.

Pada siklus 2 dilakukan penilaian menggunakan game edukasi quiziz untuk melihat keaktifan pesera didik dalam 
mengerjakan soal dengan baik dan tepat waktu.

\section{KESIMPULAN}

Penelitian tindakan kelas yang telah dilaksanakan di kelas XI IPS 1 SMA Islam Al Azhar 7 Solo Baru terdiri dari prasiklus, siklus I dan siklus II. Penerapan model problem based learning dengan berbantuan quizziz dapat meningkatkan hasil belajar sosiologi materi diferensiasi dan stratifikasi sosial pada peserta didik kelas XI IPS 1 SMA Islam Al Azhar 7 Solo Baru Tahun Pelajaran 2020/2021. Hasil kegiatan prasiklus menunjukkan keaktifan siswa dalam mengikuti pembelajaran jarak jauh kurang, hanya 10 atau $50 \%$ siswa aktif dalam pembelajaran jarak jauh dan mengerjakan tugas. Setelah dilakukan refleksi maka dilakukan siklus 1. Dalam penerapan siklus I diperoleh data
6 peserta didik yang tidak mengumpulkan tugas sesuai yang diperintahkan, sehingga hanya 14 anak yang aktif mengerjakan dan mengumpulkan tugas dengan baik.

Prosentase keaktifan peserta didik dalam mengerjakan soal di kelas XI IPS 1 adalah $70 \%$. Setelah dilakukan berbagai refleksi maka dilakukan siklus II dengan hasil 1 anak yang tidak mengerjakan quiziz, sehingga 19 anak mengerjakan dengan baik. Prosentase keaktifan kelas XI IPS 1 adalah $95 \%$.

$$
\text { Dengan demikian dapat }
$$
disimpulkan bahwa metode problem based learning dengan berbantuan quiziz dapat meningkatkan hasil belajar sosiologi materi diferensiasi dan stratifikasi sosial pada peserta didik kelas XI IPS 1 SMA Islam Al Azhar 7 Solo Baru, siklus I dan siklus II mengalami peningkatan yang signifikan.

\section{Daftar Pustaka}

Iskandar. (2012). Penelitian Tindakan Kelas. Jakarta Selatan : GP Press Group

Suprihatiningrum, J. (2013). Strategi Pembelajaran, Teori dan Aplikasi. Yogyakarta : Ar-Ruzz Media

Trianto. (2011). Penelitian Tindakan Kelas. Jakarta : Prestasi Pustaka Raya http://eprints.uny.ac.id/21010/1/Prabaria\%20Vesca\%20Yulianandra\%2010520241017.pdf http://ojs.ikipmataram.ac.id/index.php/pedagogy/article/view/2645

https://lms01-ppgdaljab.simpkb.id/ https://p4tkipa.kemdikbud.go.id/blog/index.php/2018/06/28/tpack-framework/ 